\title{
EFEKTIFITAS TERAPI AKUPRESUR TERHADAP DERAJAT NEUROPATI PADA PASIEN DIABETES MELITUS
}

\author{
Defrima Oka Surya ${ }^{1}$, Ria Desnita ${ }^{2}$
}

\author{
1Dosen Prodi D III Keperawatan STIKes MERCUBAKTIJAYA Padang \\ Email : defrima.okasurya@gmail.com \\ ${ }^{2}$ Dosen Prodi S1 Keperawatan STIKes MERCUBAKTIJAYA Padang \\ Email : ria.desnita18@gmail.com
}

\section{ABSTRACT : EFFECTIVENESS OF ACUPRESSURE THERAPY ON THE DEGREE OF NEUROPATHY IN DIABETES MELITUS PATIENTS}

Background : Diabetic neuropathy is a frequent complication of the diabetic foot. Acupressure therapy is useful in stimulating the flow of energy in the body thereby improving the flow of the body's circulation.

Purpose : This study aims to determine the effectiveness of acupressure on the degree of diabetic neuropathy in patients with diabetes mellitus.

Methods : The design of this study was a quasi-experimental study with a preposttest design without control group approach to 17 respondents. Acupressure therapy is given for 7 sessions, 2 days for 10 minutes. The degree of neuropathy was assessed using the Michigan Neuropathy Instrument Scale. To see the effect of acupressure on the degree of neuropathy in patients with diabetes mellitus, a paired $t$ test was performed with a $95 \%$ confidence level used was $95 \%$

Results : The results showed the average degree of neuropathy in Diabetes Mellitus patients before the acupressure intervention was 5.82 and after the intervention 3.68. The results of bivariate analysis showed acupressure was effective in reducing the degree of neuropathy in patients with diabetes mellitus $(p=0.001)$.

Conclusion : Acupressure therapy is effective in reducing the degree of neuropathy in Diabetes Mellitus patients. Acupressure can be used as an alternative therapy that can be applied by nurses in the community to prevent further complications in people with diabetes as a vulnerable group.

Keywords: Diabetic Neuropathy, Diabetes Melitus, Acupressure

\section{INTISARI : EFEKTIFITAS TERAPI AKUPRESUR TERHADAP DERAJAT NEUROPATI PADA PASIEN DIABETES MELITUS}

Pendahuluan : Neuropati diabetik merupakan komplikasi yang sering terjadi pada kaki Diabetisi. Terapi akupresur bermanfaat dalam menstimulasi aliran energi dalam tubuh sehingga memperbaiki aliran sirkulasi tubuh.

Tujuan : Penelitian ini bertujuan untuk mengetahui efektifitas akupresur terhadap derajat neuropati diabetik pada pasien Diabetes Melitus.

Metode : Desain penelitian ini adalah quasi eksperimen dengan pendekatan pre-posttest design without control grup pada 17 responden. Terapi akupresur diberikan selama 7 sesi, 2 hari sekali selama 10 menit. Derajat neuropati dinilai menggunakan Michigan Neuropathy Instrument Scale. Untuk melihat efek

Defrima Oka Surya 1 , Ria Desnita ${ }^{2}$

${ }^{1}$ Dosen STIKes MERCUBAKTIJAYA Padang. Email : defrima.okasurya@gmail.com

${ }^{2}$ Dosen Prodi S1 Keperawatan STIKes MERCUBAKTIJAYA Padang. Email : ria.desnita18@gmail.com 
akupresur terhadap derajat neuropati pada pasien Diabetes Melitus dilakukan uji bivariat paired $t$ test.

Hasil Penelitian : Hasil penelitian menunjukkan rerata derajat neuropati pada pasien Diabetes Melitus sebelum dilakukan intervensi akupresur adalah 5,82 dan sesudah intervensi 3,68. Hasil analisis bivariat menunjukkan akupresur efektif dalam menurunkan derajat neuropati pada pasien Diabetes Melitus $(p=0,001)$.

Kesimpulan : Terapi akupresur efektif dalam menurunkan derajat neuropati pada pasien Diabetes Melitus. Akupresur dapat dijadikan salah satu alternatif terapi yang dapat diterapkan perawat di masyarakat untuk mencegah terjadinya komplikasi lanjut pada Diabetisi sebagai kelompok rentan.

Kata kunci: Neuropati Diabetik, Diabetes Melitus, Akupresur

\section{PENDAHULUAN}

Diabetes Melitus (DM) merupakan penyakit metabolik kronik yang dicirikan dengan dengan tingginya kadar glukosa darah atau hiperglikemia. Kondisi hiperglikemia pada penderita DM disebabkan oleh ketidakcukupan hormon insulin yang dihasilkan oleh pankreas atau ketika insulin tidak dapat digunakan secara efektif oleh tubuh. Hormon insulin yang dihasilkan oleh pankreas diperlukan untuk transfer glukosa dari sel darah ke sel tubuh. Ketika jumlah hormon insulin tidak dihasilkan dalam jumlah yang cukup ataupun ketika tubuh tidak mampu menggunakan insulin secara efektif maka akan menimbulkan gangguan metabolisme glukosa yang dicirikan dengan tingginya kadar glukosa darah atau hiperglikemia (Black \& Hawk, 2014).

Angka kejadian penyakit DM terus mengalami peningkatan dari tahun ke tahun, baik di dunia maupun di Indonesia. Berdasarkan data dari International Diabetes Federation (IDF) tahun 2015, sebanyak 415 juta jiwa orang menderita penyakit DM atau mencapai 5,6\% dari total penduduk dunia. IDF memperkirakan akan terus terjadi peningkatan penderita DM hingga mencapai 642 juta jiwa di tahun 2040. Berdasarkan data studi populasi DM di berbagai negara oleh IDF tahun 2015, menunjukkan bahwa jumlah penderita DM di Indonesia mencapai 10 juta jiwa. Indonesia menempati urutan negara ke 7 di dunia dengan penderita DM terbanyak. Berdasarkan data dari World Health Organization juga menunjukkan bahwa total penderita DM di Indonesia berjumlah 7\% dari total penduduk Indonesia. Di Kota Padang sendiri, total penderita DM juga mengalami peningkatan dan pada tahun 2018 angka kejadian DM paling banyak di Kota Padang adalah di Puskesmas Andalas.

DM menimbulkan gangguan sistemik yang dapat menimbulkan berbagai komplikasi pada tubuh baik komplikasi makrovaskuler maupun mikrovaskuler. Salah satu komplikasi DM adalah gangguan neuropati diabetik pada kaki. Neuropati diabetik merupakan akibat yang terjadi karena paparan hiperglikemia kronis secara terusmenerus sehingga menimbulkan kerusakan saraf yang dapat bersifat lokal dan difus Hiperglikemia kronis menimbulkan konsentrasi glukosa di saraf juga tinggi. Glukosa akan diubah menjadi sorbitol dan fruktosa oleh enzim aldose reductase dan sorbitol dehydrogenase. Membran sel saraf bersifat tidak permiabel terhadap enzim aldose reductase dan sorbitol

Defrima Oka Surya1, Ria Desnita²

${ }^{1}$ Dosen STIKes MERCUBAKTIJAYA Padang. Email : defrima.okasurya@gmail.com

${ }^{2}$ Dosen Prodi S1 Keperawatan STIKes MERCUBAKTIJAYA Padang. Email : ria.desnita18@gmail.com 
dehydrogenase sehingga akan terjadi penumpukan ke dua enzim ini di saraf. Penumpukan enzim ini akan menimbulkan penurunan kecepatan konduksi saraf dan berujung dengan neuropati (KuateTegueu, Temfack, Ngankou, Doumbe, Djientcheu, \& Kengne, 2015).

Komplikasi DM berupa neuropati Diabetik adalah masalah yang sering terjadi pada penderita DM. Hasil penelitian Kuate-Tegueu et al. (2015) menunjukkan bahwa hampir $50 \%$ pasien DM mengalami komplikasi berupa neuropati. Prevalensi neuropati cukup tinggi dibandingkan dengan komplikasi lainnya, yaitu diperkirakan sebesar 8\% pada pasien yang baru terdiagnosa DM dan lebih dari 50\% pada pasien yang sudah lama terdiagnosa DM (Deli, Bosnyak, Pusch, Komoly, \& Feher, 2014).

Neuropati diabetik menjadi faktor resiko terjadinya komplikasi lanjut pada penderita DM berupa luka kaki diabetik. Luka kaki diabetik menjadi penyebab utama adanya hospitalisasi pada pasien DM (Gemechu, Seemant, \& Curley, 2013). Lebih dari 50\% kejadian amputasi non traumatik kaki terjadi pada pasien DM dan lebih dari $85 \%$ dicetuskan oleh luka kaki diabetik yang sudah disertai infeksi (Gemechu et al., 2013). Luka kaki diabetik akan berdampak pada penurunan kemampuan fisik, psikologis dan sosial ekonomi bagi pasien dan keluarganya. Luka kaki diabetik menyebabkan penurunan kemampuan fisik dalam melakukan aktivitas sehari-hari, menurunkan produktivitas sehingga tingkat ketergantungan pada keluarga meningkat. Luka kaki diabetik juga menimbulkan masalah psikologis seperti depresi bagi penderitanya. Bila sudah disertai dengan infeksi ke tulang (osteomielitis) maka pasien akan beresiko dilakukan amputasi (Smeltzer \& Bare, 2008).

Untuk mencegah terjadinya luka kaki diabetik dapat dilakukan dengan pengurangan gejala neuropati. Tindakan pencegahan dapat dilakukan dengan perawatan kaki, senam kaki, masase kaki ataupun terapi komplementer. Salah satu terapi komplementer yang dapat digunakan untuk mengontrol terjadinya neuropati dan perbaikan sirkulasi ke kaki adalah terapi akupresur.

Akupresur juga merupakan tindakan keperawatan yang diakui sebagai intervensi mandiri perawat dalam Nursing Intervention Classifications.

Akupresur merupakan suatu metode pengobatan dengan memberikan penekanan pada titik meridian atau titik akupunktur yang memicu terjadinya aliran energi dalam tubuh sehingga memperbaiki aliran sirkulasi tubuh. Dari hasil penelitian yang dilakukan oleh Surya (2018) menunjukkan bahwa akupresur yang dilakukan pada beberapa titik akupresur di kaki dapat meningkatkan aliran darah ke kaki, peningkatan aliran darah ini ditandai dengan peningkatan nilai ankle brachial index $(\mathrm{ABI})$.

Penelitian Surya (2018) juga menemukan bahwa akupresur dapat meningkatkan sensitivitas kaki pada diabetisi. Hasil penelitian terdahulu hanya menunjukkan efektifitas akupresur terhadap peningkatan nilai $\mathrm{ABI}$ dan sensitivitas kaki, sedangkan bagaimana efektifitas akupresur terhadap skor neuropati secara keseluruhan tidak dilihat dalam penelitian tersebut.

Hasil studi pendahuluan terhadap 10 orang pasien DM tipe II didapatkan 8 orang pasien memiliki

Defrima Oka Surya1, Ria Desnita²

${ }^{1}$ Dosen STIKes MERCUBAKTIJAYA Padang. Email : defrima.okasurya@gmail.com

${ }^{2}$ Dosen Prodi S1 Keperawatan STIKes MERCUBAKTIJAYA Padang. Email : ria.desnita18@gmail.com 
keluhan neuropati yaitu berupa kebas di kaki, kram pada di malam hari. 8 pasien ini dilakukan pemeriksaan fisik neuropati dan ditemukan tampilan umum kaki kering, penurunan sensitivitas kaki dan reflek ankle. Hasil skor neuropati rata-rata pada 8 pasien tersebut didapatkan nilai 5,6, artinya pasien tersebut positif mengalami neuropati diabetik. Hasil wawancara lanjut didapatkan bahwa upaya yang dilakukan pasien untuk mengatasi keluhan di kakinya hanya berupa merendam kaki di air hangat dan belum ada pasien yang mendapatkan penanganan berupa terapi akupresur untuk mengatasi masalah kakinya.

Berdasarkan fenomena yang ada dan penjelasan penelitian terdahulu maka peneliti akan melakukan penelitian lebih lanjut tentang "Efektivitas akupresur terhadap derajat neuropati pada pasien Diabetes Melitus".

\section{METODE PENELITIAN}

Kriteria inklusi penelitian ini adalah bersedia menjadi responden penelitian, pasien dengan diagnosis Diabetes Melitus dan tertulis di data rekam medis puskesmas, pasien dengan $A B I<1,1$, pasien dengan komplikasi neuropati diabetik berdasarkan skrining dengan Michigan Neuropaty Screening Instrument (MNSI). Kriteria eksklusi dalam penelitian ini adalah terdapat ulkus diabetik di kaki, edema di kaki da nada penyakit kulit di kaki. Besar sampel pada penelitian ini adalah 17 orang. Teknik pengambilan sampel dilakukan dengan teknik consecutive sampling yaitu mempertimbangkan kriteria inklusi dan eksklusi.

Pada penelitian ini intervensi akupresur diberikan sebanyak 7 sesi, selama 10 menit, sekali dalam 2 hari. Prosedur terapi akupresur dilakukan sesuai pedoman praktis akupresur (Yapeptri, 2008). Derajat neuropati dinilai menggunakan Michigan Neuropathy Instrument Scale. Penelitian dilakukan dengan memperhatikan etika penelitian sesuai dengan nomor surat izin penelitian : 142d/LP2M$M C B / X I I / 2019$.

Untuk melihat efek akupresur terhadap derajat neuropati pada pasien Diabetes Melitus dilakukan uji bivariat paired $t$ test dengan tingkat kepercayaan yang digunakan adalah $95 \%$. Analisis data dilakukan menggunakan aplikasi spss 21 .

\section{HASIL PENELITIAN}

\section{Karakteristik Responden}

Gambaran karakteristik responden pada penelitian ini dapat dilihat pada tabel 1 berikut:

Tabel 1

Distribusi Usia, Lama Menderita DM, dan Derajat Neuropati pada Pasien Diabetes Melitus di Wilayah Kerja Puskesmas Nanggalo $(n=17)$

\begin{tabular}{lllc}
\hline \multicolumn{1}{c}{ Variabel } & Mean & SD & Min-Maks \\
\hline Usia & 52,41 & 5,62 & $39-60$ \\
& & & \\
\hline $\begin{array}{l}\text { Lama Menderita } \\
\text { DM }\end{array}$ & 4,59 & 1,84 & $2-8$ \\
\hline $\begin{array}{l}\text { Derajat Neuropati } \\
\text { Pretest }\end{array}$ & 5,82 & 1,03 & $4-8$ \\
Postest & 3,68 & 1,19 & $2,5-6$ \\
\hline
\end{tabular}

Defrima Oka Surya ${ }^{1}$, Ria Desnita ${ }^{2}$

${ }^{1}$ Dosen STIKes MERCUBAKTIJAYA Padang. Email : defrima.okasurya@gmail.com

${ }^{2}$ Dosen Prodi S1 Keperawatan STIKes MERCUBAKTIJAYA Padang. Email : ria.desnita18@gmail.com 
Berdasarkan tabel 1 diketahui bahwa rerata usia pasien Diabetes Melitus yang menjadi responden penelitian di Wilayah Kerja Puskesmas Nanggalo Padang adalah 52,41 tahun, rerata lama menderita DM adalah 4,59 tahun. Rerata derajat neuropati sebelum intervensi adalah 5,82 dan rerata derajat neuropati sesudah intervensi adalah 3,68.

2. Perbedaan Derajat Neuropati Sebelum dan Sesudah Intervensi Perbedaan derajat neuropati sebelum dan sesudah diberikan terapi akupresur pada pasien hemodialisis dapat dilihat pada tabel 2 berikut.

Tabel 2

Perbedaan Derajat Neuropati Sebelum dan Setelah Diberikan Intervensi Akupresur pada Pasien Diabetes Melitus di Wilayah Kerja Puskesmas Nanggalo $(n=17)$

\begin{tabular}{lcccc}
\hline Variabel & \multicolumn{3}{c}{ Intervensi (n=17) } & P \\
\cline { 2 - 3 } & Mean & SD & $\begin{array}{r}\text { Beda } \\
\text { Mean }\end{array}$ & \\
\hline $\begin{array}{l}\text { Derajat } \\
\text { Neuropati }\end{array}$ & & & & \\
$\quad \begin{array}{l}\text { Sebelum } \\
\text { Sesudah }\end{array}$ & 5,82 & 1,03 & 2,14 & $0,001^{*}$ \\
\hline & 3,68 & 1,19 & & \\
\hline *bermakna pada $\alpha: 0,05$ & &
\end{tabular}

Berdasarkan tabel 2 di atas, terlihat perbedaan derajat neuropati sebelum intervensi dan sesudah intervensi adalah 2,14. Hasil analisis lebih lanjut menunjukkan terapi akupresur efektif dalam menurunkan derajat neuropati pada pasien Diabetes Melitus $(p=0,001)$.

\section{PEMBAHASAN}

Berdasarkan hasil penelitian didapatkan rentang usia responden adalah 39 - 60 tahun, dengan rerata usia 52,41 tahun. Rentang usia responden merupakan rentang usia yang memiliki resiko terkena Diabetes Melitus. Risiko insiden Diabetes tipe 2 mulai meningkat pada usia di atas 30 tahun (Booya et al., 2005). Risiko terjadinya komplikasi DM seperti neuropati diabetik juga meningkat seiring dengan pertambahan usia. Proses penuaan menyebabkan terjadinya perubahan anatomi, fisiologi dan biokimia sel, termasuk sel saraf dan pembuluh darah. Perubahan pada struktur dan fisiologi saraf menyebabkan penurunan konduksi saraf sehingga juga menyebabkan penurunan hantaran konduksi saraf di perifer. Salah satu manifestasi penurunan hantaran saraf di perifer adalah penurunan sensitivitas kaki, penurunan persepsi getar dan reflek ankle. Sedangkan perubahan pembuluh darah seperti terjadinya aterosklerosis menyebabkan penurunan aliran darah termasuk aliran darah tungkai sehingga juga mencetuskan kondisi neuropati (Verdu, Ceballos, Vilches, \& Navarro, 2000).

Berdasarkan hasil penelitian ditemukan bahwa rerata lama menderita DM pada responden adalah 4,59 tahun. Terjadinya komplikasi DM berupa neuropati tidak berhubungan langsung dengan lama menderita DM. Terjadinya

Defrima Oka Surya ${ }^{1}$, Ria Desnita ${ }^{2}$

${ }^{1}$ Dosen STIKes MERCUBAKTIJAYA Padang. Email : defrima.okasurya@gmail.com

${ }^{2}$ Dosen Prodi S1 Keperawatan STIKes MERCUBAKTIJAYA Padang. Email : ria.desnita18@gmail.com 
komplikasi lebih dihubungkan dengan lamanya paparan seseoang terhadap kondisi hiperglikemia kronik. Hiperglikemia kronik akan menyebabkan terjadinya peningkatan kadar glukosa di saraf. Tingginya kadar glukosa di saraf akan mengaktivasi enzim aldose reduktase dan sorbitol dehydrogenase sehingga merubah glukosa menjadi sorbitol dan fruktosa. Sorbitol dan fruktosa menyebabkan terjadinya gangguan konduksi saraf sehingga dapat menurunkan sensasi kaki (Veves, Giurini, \& LoGervo, 2012).

Berdasarkan hasil penelitian didapatkan perbedaan bermakna derajat neuropati sebelum dan sesudah diberikan terapi akupresur $(p=0,001)$. Hasil penelitian ini sejalan dengan penelitian Tong et al. (2010) yang melakukan akupunktur selama 7 sesi terhadap 42 orang Diabetisi neuropati. Tong et al. (2010) menyatakan terdapat pengaruh akupunktur terhadap penurunan gejala neuropati motorik dan sensorik pasien neuropati diabetik $(p<0,05)$.

Esensi kesamaan penelitian ini dengan penelitian Tong et al. (2010) adalah akupresur merupakan pemijatan yang dilakukan pada titik akupunktur. Akupresur merupakan salah satu bentuk terapi sentuhan (touch therapy) yang didasarkan pada prinsip ilmu akupunktur dan pengobatan Cina, dimana beberapa titik yang terdapat pada permukaan tubuh dirangsang dengan penekanan jari (Dupler, 2005).

Mekanisme dasar terapi akupresur untuk memperbaiki gejala neuropati pada Diabetisi adalah dengan memperbaiki sirkulasi darah ke kaki. Stimulasi yang dilakukan pada titik akupresur dapat menstimulator reseptor sensori dan fungsi saraf otonom sehingga menimbulkan vasoaktif neuropeptida seperti calcitonin gene-related peptide (CGRP) dan substansi $P$ (SP) dan akhirnya melancarkan aliran darah (Shuji et al., 2009). Titik akupunktur merupakan titik perangsangan untuk menimbulkan keseimbangan kesehatan tubuh (Sukanta 2008). Titik-titik akupuntur menyebar di jalur meridian yang merupakan jalur energi. Stimulasi yang dilakukan untuk menurunkan gejala neuropati dengan melakukan pemijatan pada titik LR3, K13, SP6, SP10 dan ST36 dapat menstimulasi reseptor sensori yang ada di kaki sehingga mempengaruhi konduksi saraf di kaki (Tong et al., 2010).

Teknik akupresur bertujuan untuk membangun kembali sel-sel dalam tubuh yang melemah serta mampu meregenerasikan sel tubuh, memperlancar aliran darah sehingga memperbaiki fungsi sel tubuh dan mengurangi sel abnormal (Fengge, 2012). Jika dibandingkan dengan kondisi Diabetisi yang mengalami komplikasi neuropati, maka dengan pemberian terapi akupresur dapat meregenerasi sel saraf.

Teori dasar akupresur menjelaskan bahwa manusia terdiri dua aspek yaitu Yin dan Yan yang saling mendasari dan mempengaruhi. Yin adalah sesuatu yang bersifat pasif, sedangkan Yang bersifat lebih aktif (Loupatty et al.,1996; Cheung, Li \& Wong, 2001; Sukanta, 2008). Jika dikaitkan dengan kondisi Diabetisi dengan kondisi mengalami komplikasi bisa diartikan bahwa unsur Yin atau Yang dalam tubuh Diabetisi tidak seimbang. Jika salah satu lebih dominan maka kesehatan terganggu atau tidak sehat. Tujuan akupresur

Defrima Oka Surya ${ }^{1}$, Ria Desnita ${ }^{2}$

${ }^{1}$ Dosen STIKes MERCUBAKTIJAYA Padang. Email : defrima.okasurya@gmail.com

${ }^{2}$ Dosen Prodi S1 Keperawatan STIKes MERCUBAKTIJAYA Padang. Email : ria.desnita18@gmail.com 
adalah untuk menyeimbangkan Yin dan Yang.

Pada Diabetisi, kondisi kekurangan insulin dan hiperglikemia menyebabkan terjadinya penurunan nerve growth factor (NGF). NGF berperan dalam regenerasi saraf. Pada Diabetisi, berkurangnya NGF menyebabkan saraf yang rusak tidak mengalami perbaikan. Dengan pemberian terapi akupresur, dapat menstimulasi perbaikan saraf dengan meningkatkan NGF. Perbaikan regenerasi saraf dengan pemberian akupresur dapat menyebabkan peningkatan konduksi saraf sehingga mengurangi gejala neuropati (Baeumler et al., 2014).

\section{KESIMPULAN}

Berdasarkan hasil penelitian dapat disimpulkan rerata derajat neuropati pada pasien Diabetes Melitus sebelum diberikan intervensi akpresur adalah 5,82. Rerata derajat neuropati pada pasien Diabetes Melitus setelah diberikan intervensi akupresur adalah 3,68. Hasil analisis bivariat dengan paired t-test menunjukkan akupresur efektif dalam menurunkan derajat neuropati pada pasien Diabetes Melitus ( $p=0,001)$

\section{SARAN}

Terapi akupresur dapat menjadi peluang bagi perawat komunitas khususnya di Wilayah Kerja Puskesmas Nanggalo Kota Padang untuk mengembangkan pelayanan keperawatan komplementer di masyarakat untuk mencegah terjadinya komplikasi lanjut Diabetes Melitus. Diharapkan Puskesmas dapat memberikan pelatihan akupresur khususnya bagi perawat sehingga perawat bias menjadi terapis yang tersertifikasi di tengah masyarakat.

\section{DAFTAR PUSTAKA}

Black, J. M, \& Hawks, J. H. (2010). Medical-surgical nursing: Clinical management for positive outcome. St.Louis: Saunders Elsevier

Bulechek, G. M., Dochterman, J. M., Butcher, H. K., \& Wagner, C. M. (2015). Nursing intervention classification (NIC). St.Louis: Mosby.

Dahlan, M. S. (2013). Besar sampel dan cara pengambilan sampel dalam penelitian kedokteran dan kesehatan. Jakarta: Salemba Medika.

Deli, G., Bosnyak, E., Pusch, G., Komoly, S., \& Feher, G. (2014). Diabetic neuropathies: Diagnosis and management.

Neuroendocrinology, 98(4), 267-280.

doi:http://dx.doi.org/10.11 59/000358728

Dergisi, H. Y. (2006). Acupressure. Journal of Hacetteppe University School of Nursing, 304, 43-47.

Fengge, A. (2012). Terapi akupresur : Manfaat dan teknik pengobatan. Edisi 1. Yogyakarta: Circle Crop

Garrow, A. P., Xing, M., Vere, J., Verrall, B., Wang, L., \& Jude, E. B. (2014). Role of acupuncture in the management of diabetic painful neuropathy (DPN): a pilot RCT. Acupuncture

Defrima Oka Surya1, Ria Desnita²

${ }^{1}$ Dosen STIKes MERCUBAKTIJAYA Padang. Email : defrima.okasurya@gmail.com

${ }^{2}$ Dosen Prodi S1 Keperawatan STIKes MERCUBAKTIJAYA Padang. Email : ria.desnita18@gmail.com 
Medical, 32, 242-249.

Gemechu, F. W., Seemant, F., \& Curley, C. A. (2013). Diabetic foot infections. American Family Physician, 88(3), 177-184.

International Diabetes Federation. (2015). IDF diabetes atlas 2015. Retrieved from http://www.diabetesatlas. org/resources/2015atlas.html

Kementrian Kesehatan RI. (2015). Pedoman pembinaan pengobatan tradisional akupresur. Jakarta: Balitbang Kemenkes RI.

Kuate-Tegueu, C., Temfack, E., Ngankou, S., Doumbe, J., Djientcheu, V. P., \& Kengne, A. P. (2015). Prevalence and determinants of diabetic polyneuropathy in a subSaharan African referral hospital. Journal of the Neurological Sciences, 355, 108-112.

http://doi.org/10.1016/j.jn s.2015.05.035

Shuji, S., Ichioka, S., Omata, H., Yamaguchi, S., Mimura, T., \& Nakatsuka, T. (2009). Effect of acupuncture on lower limb ischemia. Journal Saitama Medical University, 36, 1-10.

Smeltzer, S., \& Bare. (2008). Brunner \& Suddarth's Textbook of medical surgical nursing.

Philadelpia: Lippincott.
Surya, D. O. (2018). Akupresur efektif meningkatkan ankle brachial index pada diabetisi. Jurnal Endurance, 3(2), 408 - 414.

University of Michigan. (2000). Michigan Neuropathy Screening Instrument. Retrieved from http://www.med.umich.ed u/borc/profs/documents/sv i/MNSI_patient.pdf

Yapeptri. (2008). Pedoman Praktis Akupresur. Jakarta : Departemen Kesehatan RI. Direktorat Jendral Pembinaan Kesehatan Masyarakat. Direktorat Bina Peran Serta Masyarakat. Tidak dipublikasikan. 